Abdolpour, H.; Escusa, G.; Sena-Cruz, J.; Valente, I.; Barros, J. (2017) "Axial performance of jointed sandwich wall panels." Journal of Composites for Construction, 21(4): 04017009 1 04017009-12.

\title{
Axial performance of jointed sandwich wall panels
}

Hassan Abdolpour ${ }^{1, a}$, Gonçalo Escusa ${ }^{2, a}$, José M. Sena-Cruz ${ }^{3, a}$, Isabel B. Valente ${ }^{4, a}$, Joaquim

$$
\text { A.O. Barros }{ }^{5, \mathrm{a}}
$$

${ }^{a}$ ISISE, University of Minho, Guimarães, Portugal

\section{Abstract}

Throughout this paper, a new system for connecting composite sandwich wall panels is proposed. The relevant structural components are investigated with the aim of utilizing these panels as insulated wall elements in building applications or prefabricated modular systems. The adopted sandwich wall panels are composed of hand-layup Glass Fiber Reinforced Polymer (GFRP) outer skins and low density closed polyurethane (PU) foam core. The sandwich wall panels present an overall geometry of $2880 \times 960 \times 64 \mathrm{~mm}^{3}$. One challenge of the proposed new system that was examined included joining the panels in the longitudinal direction (along their height) and transversally connecting (along their width) to other structural elements, similar to beams at the bottom and top. The structural performance of the sandwich wall panels was experimentally tested and thereafter analytically assessed in two cases: (i) single wall panels; (ii) two jointed wall panels. Outward localized GFRP wrinkling, followed by global buckling was observed as the dominant failure mode in both cases. Further, the capability of the proposed connection system to increase the axial load capacity

1Ph.D. Candidate, Dept. of Civil Engineering, Univ. of Minho,Campus de Azurém, 4810-058 Guimarães, Portugal (corresponding Author). E-mail: hassan.abdolpour@gmail.com

2Civil Engineer Researcher, Dept. of Civil Engineering, Univ. of Minho,Campus de Azurém, 4810-058 Guimarães, Portugal. Email: g.escusa@gmail.com

3Associate Professor, Dept. of Civil Engineering, Univ. of Minho,Campus de Azurém, 4810-058 Guimarães, Portugal. E-mail: jsena@civil.uminho.pt

4Assistant Professor, Dept. of Civil Engineering, Univ. of Minho,Campus de Azurém, 4810-058 Guimarães, Portugal. E-mail: isabelv@.civil.uminho.pt

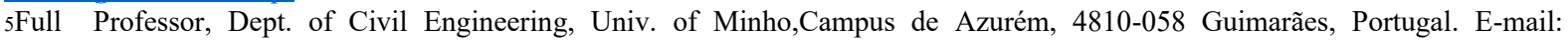
barros@civil.uminho.pt 
Abdolpour, H.; Escusa, G.; Sena-Cruz, J.; Valente, I.; Barros, J. (2017) “Axial performance of jointed sandwich wall panels.” Journal of Composites for Construction, 21(4): 04017009 1 04017009-12.

of the jointed panels was evaluated. The study illustrates that axial capacity of two jointed sandwich wall panels compared to the single sandwich wall panel, increased substantially from $91 \%$ to $152 \%$ depending on the failure modes.

Keywords: Composite materials; Sandwich wall panels; GFRP skins; PU foam core; Buckling load; jointed wall panels.

\section{Introduction}

During the past several years, the increased demand for new efficient structural systems comprised of composite materials has led to the investigation of eco-friendly, lightweight and durable sandwich composites. Sandwich wall panels, made of composite materials, have reasonable thermal-acoustic performance when compared to other traditional technologies. Additionally, sandwich composites exhibit high strength-to-weight ratios, making them suitable for applications like wall systems. For this reason, the application of sandwich wall panels in housing systems has become a topic of further investigation. Currently, modular housing systems are becoming more popular, due to the advantages that modular construction provides, including faster and easier assembly with less labour. Sandwich composites help to further streamline modular structural design with a lighter and stronger materials.

Several experimental and theoretical investigations have been carried out by different researchers to evaluate the behavior of composite sandwich wall panels and their failure modes under eccentric or concentric axial loads. Recently, Mathieson and Fam (2015) performed an in-depth study to investigate the influence of the slenderness ratio on the concentric axial behavior of sandwich wall panels. Different failure modes, namely buckling, GFRP wrinkling failure, core shear failure, and GFRP crushing failure were observed. Also, the axial load capacity of the panels and observed failure modes were correlated to the 
Abdolpour, H.; Escusa, G.; Sena-Cruz, J.; Valente, I.; Barros, J. (2017) “Axial performance of jointed sandwich wall panels." Journal of Composites for Construction, 21(4): 040170091 04017009-12. slenderness ratio as well as the nature of sandwich panels, namely the influence of the internal ribs. Based on the obtained results, the authors have proposed simplified equations for predicting the load carrying capacity of the panels. Mousa and Uddin (2012) studied the structural behavior of sandwich wall panels under eccentric loading. The dominant failure mode was described as an abrupt debonding between the GFRP skin and the foam core in the compression side due to out-of-plane interfacial tensile stresses that are higher than the ultimate tensile strength of the foam core material, known as wrinkling failure mode or local buckling. The authors of this study also developed an analytical model to justify the observed wrinkling failure mode by considering two kinds of stresses associated to it: (i) interfacial tensile strength between GFRP skin and foam core; and, (ii) the critical wrinkling stress in the compressive GFRP skin.

Different theoretical approaches can be used to analyse the instability that occurs in composite sandwich wall panels. The basic approach was proposed by Euler using the wellknown Euler-Bernoulli assumption, where the global buckling load is predicted under various support conditions and slenderness ratios. It was observed that the effect of transversal shear (out-of-plane shear components) can significantly reduce the Euler critical load. Based on that, Engesser (1981) and Haringx (1948) proposed to include shear deformation in the analysis of axially loaded composite panels. The nonlinear geometrical behavior of sandwich panels using high-order theory was further developed under various boundary conditions (Frostig 1998, Frostig and Barnch 1993).

The investigations conducted pertain to sandwich panel units, composed of GFRP skins and PU foam core, with an overall geometry of $2880 \times 960 \times 64 \mathrm{~mm}^{3}$. Joining composite sandwich wall panels is a different challenge level, and may lead to distinct behavior. Therefore, this work intends to experimentally assess to the structural behavior under 
Abdolpour, H.; Escusa, G.; Sena-Cruz, J.; Valente, I.; Barros, J. (2017) “Axial performance of jointed sandwich wall panels." Journal of Composites for Construction, 21(4): 040170091 04017009-12.

concentric axial loads of both individual and two jointed composite sandwich wall panels by using an innovative connecting system. Aspects related to assembly and disassembly, as well as ease of integration in the production line, were also considered. Finally, analytical investigations were carried out to determine the axial capacity and stresses associated with various failure modes, both in single panels and two jointed panels.

\section{Problem statement and technical considerations}

Different techniques for connecting FRP panels in modular housing system applications are documented in the literature. Some of these techniques are depicted in Fig. 1. For instance, 'Z'-shaped adhesively connected techniques (Fig. 1a) have been employed for connecting sandwich panels in the rehabilitation of building floors (Garrido, et al. 2015) and in bridge decks (Keller, et al. 2014). In this type of connection, Z-joint was adapted and integrated at each ends of sandwich panels during the manufacturing process. The anti-symmetrically configuration of the connection facilitated the panels to joint together by using adhesive. The main problem of this connection in modular systems is the need of adhesive for integrating the two components. Using adhesive requires time for curing and specific treatment, which increases the time of construction and requires suitable temperatures for the curing process. Additionally, it is fairly difficult to only replace one panel, because all the panels are adhesively jointed. In this case, it might be necessary to replace the entire jointed panel, which can be a relatively expensive process. Scarfed and stepped overlap joints (Figures $1 \mathrm{~b}$ and 1c) present the best performance among bonded joints (Hart-Smith 2003). Stepped and scarf lap joints represent an adapted cross section during manufacturing lines. In this system, two parts of jointed panels, need to be aligned first and then can be fitted inside together using adhesive. This system of connections provided long overlapping and are suitable for 
Abdolpour, H.; Escusa, G.; Sena-Cruz, J.; Valente, I.; Barros, J. (2017) “Axial performance of jointed sandwich wall panels." Journal of Composites for Construction, 21(4): 04017009 1 04017009-12.

connecting the sandwich panels of higher thickness (Hart-Smith 1973). However, this type of connection results in higher complexity in the production lines and, consequently, increases the price of the produced panels. Male-female connections (Fig. 1d) have been used in bridge applications (Liu, et al. 2008, Turner, et al. 2004, Zhou and Keller 2005). In spite of providing integrity between panels and loading-transfer efficiency of the formed deck, these panels needed to be placed horizontally by employing specific instruments, such as hydraulic jacks, which is a time consuming and expensive process. The use of this technique in building applications seems to be a more demanding procedure due to spatial limitation (Garrido, et al. 2015). Tongue and groove mechanisms (Fig. 1e) are used in bridge deck applications (Mara, et al. 2014). The mechanism of this connection could be interpreted by interlocking of two parts at $45^{\circ}$ angle without using adhesive or some mechanical fasteners. Additionally, the conceptual design of this connection took into consideration aspects like rapid installation with no-skilled labor and feasibility of dismantling. The transportation of these panels must be undertaken very carefully. If a small part is damaged, the entire panel needs to be replaced. In addition, the integration of this system in production lines appears to be a major challenge.

The detailing of the connection system used in the current work, is presented in Fig. 1f. Different criteria were considered in the development of this system, namely: (i) to ensure adequate integrity and load transfer efficiency between jointed components; (ii) to guarantee practical assembly in confined spaces; (iii) to provide rapid installation of the panels with non-skilled manpower; (iv) to facilitate an easy integration in production lines; (v) to include a disassembling system for repairing or replacing purposes and (vi) to provide functional and efficient connections by adjoining entire wall panels to roof elements. Based on these criteria the proposed connection is composed of two structural components: (i) the male connector made of GFRP rectangular profile due to financial restrictions it was executed by two GFRP 
Abdolpour, H.; Escusa, G.; Sena-Cruz, J.; Valente, I.; Barros, J. (2017) “Axial performance of jointed sandwich wall panels.” Journal of Composites for Construction, 21(4): 04017009 1 04017009-12.

116 Q50 $\times 50 \times 5 \mathrm{~mm}^{3}$ profiles adhesively and mechanically bonded to become a unit, and (ii) the female connectors made of GFRP U60 $\times 50 \times 5 \mathrm{~mm}^{3}$ profiles that are the borders constituents of the sandwich panel. By using this strategy two distinct connection mechanics are mobilized depending on the type of actions: (i) interlocking and encasing provided by the male-female connection and (ii) friction at interface of those elements.

A common sandwich panel made of two outer skins and an interior core (Fig. 2a) was adopted in the present work. Prior investigations indicated that using high strength material such as Carbon Fiber Reinforced Polymer (CFRP) for the skin was not necessary and recommended to use of GFRP material (Shawkat, et al. 2008) ; additionally, PU foam material with a minimized amount of internal ribs exhibited good insulation characteristics (Sharaf, et al. 2010). In consequence, GFRP and PU foam were chosen to form the main structure of the wall panels in the present study.

The panels were designed to have the capability of joining together along their length and width, in longitudinal and transverse directions, respectively, to other elements such as beams or columns, using two kinds of pultruded profiles: (i) GFRP pultruded ' $U$ ' profiles installed along the edges of the wall panels during the manufacturing process (see Fig. 2b); (ii) tubular pultruded GFRP profiles (designated as connectors) placed inside the GFRP ' $U$ ' profile during the assembly process (see Fig. 2c).

The sandwich panels were devised to be easily assembled in this system. After installing the first wall panel, the longitudinal connector is placed inside the corresponding GFRP ' $U$ ' profile, and subsequently, another wall panel can be attached to this connector by sliding (Fig. 2d). The key manner to integrate the two wall panels is based on the mechanical interlocking of ' $U$ ' profiles with the tubular connector. 
Abdolpour, H.; Escusa, G.; Sena-Cruz, J.; Valente, I.; Barros, J. (2017) “Axial performance of jointed sandwich wall panels.” Journal of Composites for Construction, 21(4): 04017009 1 04017009-12.

The connection between two wall panels and the beams form the main structural system of the construction, which is represented in Fig. 2e. In this respect, the first wall panel slides along the transversal GFRP tubular connector (that was previously attached to the beam or roof elements) up to its target position. After placing the first wall panel into position, a longitudinal GFRP tubular connector is placed into the corresponding GFRP ' $U$ ' profile. Finally, another panel slides along the transversal GFRP tubular connectors, being connected to the previous one.

\section{Specimen description}

Six sandwich wall panels, designated as WP1 through WP6, were manufactured by company ALTO - Perfis Pultrudidos Lda., using hand-layup technique. The GFRP skins have a thickness of $2 \mathrm{~mm}$ and were produced using dry glass fibers impregnated with an isophthalic polyester resin. Multiple plies of glass fabrics were used in the process, comprising two different types of mat: chopped strand mat (CSM) and bidirectional woven fabric mat (WFM). The layered organization of each skin has the following sequence: (i) CSM-300

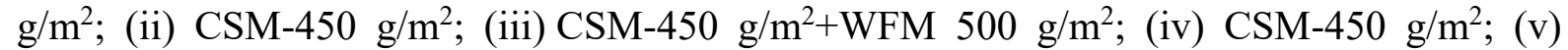
CSM-300 g/m². The total fiber volume ranges from $30 \%$ to $40 \%$ of the total skin volume with an average value of $36 \%$, having been obtained according to the recommendations of ASTM D3171-06 (2006). This relatively large interval is consequence of manufacturing process (hand-layup) adopted by the supplier. PU foam blocks with a thickness of $60 \mathrm{~mm}$ and a nominal density of $48 \mathrm{~kg} / \mathrm{m}^{3}$ were used to form the sandwich panel core. These blocks were bonded to the skin with polyester resin. With these characteristics, the designed prototype fulfils thermal insulation performance demands for housing in terms of $\mathrm{U}$-value $\left[\mathrm{W} / \mathrm{m}^{2}{ }^{\circ} \mathrm{C}\right]$ which must be between 0.4 and $1.4 \mathrm{~W} / \mathrm{m}^{2}{ }^{\circ} \mathrm{C}$. Sandwich wall panels present an overall 
Abdolpour, H.; Escusa, G.; Sena-Cruz, J.; Valente, I.; Barros, J. (2017) “Axial performance of jointed sandwich wall panels.” Journal of Composites for Construction, 21(4): 04017009 1 04017009-12.

thickness of $64 \mathrm{~mm}$, a width of $960 \mathrm{~mm}$ and a height of $2880 \mathrm{~mm}$. Each panel's weight was approximately $42 \pm 2 \mathrm{~kg}$, making them easy to transport and install on-site. In this investigation, GFRP ' $U$ ' profiles with dimensions of $60 \times 55 \times 5 \mathrm{~mm}^{3}$ were adhesively bonded to the skins and PU foam core around the edges of the panels during the manufacturing process. The two GFRP pultruded tubular square profiles $\left(2 \mathrm{Q} 50 \times 50 \times 5 \mathrm{~mm}^{3}\right)$, with a length of $2700 \mathrm{~mm}$, are considered as longitudinal connectors. These two profiles were bonded together with polyester resin and eight mechanical fasteners (M8 steel bolts), as shown in the detail 3 of Fig. 2.

Four tests of both single and jointed wall panels (WP) were carried out, using WP1 and WP2 as single wall panels and series WP3+WP4 and WP5+WP6 as jointed wall panels. These tests intend to identify the failure modes, evaluate the developed strains on the skins, assess the maximum axial loading capacity, and determine the maximum in-plane and out-ofplane deflection. Additionally, the tests with the jointed panels aim to verify the efficiency of the connector in facilitating integrity between two connected panels, as well as the connection's influence on the axial load capacity of the panel system.

\section{Experimental program}

\section{Material characterization}

The tensile properties of the GFRP profiles and sandwich panel GFRP skins were evaluated with tensile tests performed according to ASTM D3039 (2000a). Five specimens with dimensions of $250 \times 25 \times 5 \mathrm{~mm}^{3}$ were extracted from the profiles, and from the longitudinal and transversal directions of the sandwich wall panel skins, and tested with a grip distance of $150 \mathrm{~mm}$ at a monotonically displacement rate of $2 \mathrm{~mm} / \mathrm{min}$ until failure. 
Abdolpour, H.; Escusa, G.; Sena-Cruz, J.; Valente, I.; Barros, J. (2017) “Axial performance of jointed sandwich wall panels.” Journal of Composites for Construction, 21(4): 04017009 1 04017009-12.

Mechanical properties of the PU foam core were evaluated under compression, tension and shear tests. Flatwise compression properties of the PU foam were determined according to ASTM C365-03 (2005a), by testing five prism-shaped coupons of $70 \times 70 \times 50 \mathrm{~mm}^{3}$. Tensile properties of the PU foam were evaluated according to ASTM C297/C 297 M-04 (2010), by testing five coupons of $70 \times 70 \times 50 \mathrm{~mm}^{3}$ adhesively bonded to steel T-sections. Shear properties of the PU foam core were determined according to ASTM C273-00 (2000b), by testing five coupons of $720 \times 50 \times 80 \mathrm{~mm}^{3}$. All these tests were executed at a displacement rate of $0.5 \mathrm{~mm} / \mathrm{min}$.

The mechanical properties of the polyester resin used to bond the skin to the PU foam core were assessed under direct tensile test according to ASTM D638 (2004). The resin was casted in dog-bone moulds and cured following the standard recommendations. Specimens were tested in a universal testing machine at a displacement rate of $2 \mathrm{~mm} / \mathrm{min}$.

Tensile bond strength of adhesive joint between GFRP skin and PU foam core was measured by pull-off test based on ASTM 1583-04 (2005b). Five cores were drilled in the GFRP skins with the diameter of $50 \mathrm{~mm}$ and core depth of around $10 \mathrm{~mm}$. Aluminium disks were adhesively glued to the GFRP skin. Tensile force was applied to the disks with a head displacement rate of $0.2 \mathrm{~mm} / \mathrm{min}$.

\section{Axial loading test setup and instrumentation}

A self-balanced reaction axial loading frame was designed based on the estimated ultimate axial load of two jointed panels. Schematic view of this frame is shown in Fig. 3a. The frame comprised the following components: reaction beams, support system, high-strength steel DYWIDAG bars, and loading system (see Fig. 3b). 
Abdolpour, H.; Escusa, G.; Sena-Cruz, J.; Valente, I.; Barros, J. (2017) “Axial performance of jointed sandwich wall panels." Journal of Composites for Construction, 21(4): 040170091 04017009-12.

Two stiff HEB 200 steel profiles with a length of $2000 \mathrm{~mm}$ were designed as reaction beams in order to transfer axial loading to the panels. Each of these profiles was placed on the top and bottom of the specimens. The top beam was fixed to one existing steel frame with M20 steel bolts. The bottom HEB 200 profile was not fixed to any elements and was allowed to move in the axial direction of the panels (see Figures $3 \mathrm{a}$ and $3 \mathrm{c}$ ).

The specified supporting system was designed to act as a pined support at both ends of the panel (see Fig. 3d). This system comprised three segments: (i) two T-shaped steel plates; (ii) a steel cylinder and; (iii) a steel UNP profile. The two ' $T$ '-shaped steel plates had a flange dimension of $200 \times 200 \times 10 \mathrm{~mm}^{3}$ and web dimension of $200 \times 150 \times 10 \mathrm{~mm}^{3}$, and were connected together through steel cylinders with a diameter of $50 \mathrm{~mm}$ and length of $300 \mathrm{~mm}$, allowing the rotation of these two ' $\mathrm{T}$ '-shape plates. One part of the ' $\mathrm{T}$ '-shape plate was attached to the HEB 200 beam profile with four M20 steel bolts, while the other part was welded to the UNP 120 steel profile, with a length of $2000 \mathrm{~mm}$. To reduce misalignments and to distribute the load uniformly along the width of the sandwich wall panel, four of these pinned supporting systems were considered along the UNP profile at top and bottom of the wall panels (see Fig. 3c).

For applying the load from top HEB 200 beam to the bottom HEB 200 beam, four high strength steel DYWIDAG bars with a diameter of $16 \mathrm{~mm}$ were employed. These bars were locked to steel plates with dimension of $400 \times 200 \times 60 \mathrm{~mm}^{3}$ by using steel lock washers.

Two BVA hydraulic jacks with a maximum load capacity of $200 \mathrm{kN}$ and including a through-hole load cell of the same capacity were used to apply and measure the load. The pressure on the jacks was controlled manually by using a hydraulic pump. Since during the loading, the top steel plate is pushed by the hydraulic jacks, the produced tensile force in the DYWIDAG bars is transferred to the wall panel as a compression force. 
Abdolpour, H.; Escusa, G.; Sena-Cruz, J.; Valente, I.; Barros, J. (2017) “Axial performance of jointed sandwich wall panels.” Journal of Composites for Construction, 21(4): 04017009 1 04017009-12.

Single wall panels and jointed panels were instrumented with LVDTs (D) and strain gauges (S). LVDTs were placed at each quarter height of the wall panels for measuring the out-ofplane deflection of the panels, D1 to D14 where used in single panel, while D1 to D18 were implemented in the jointed panels. Likewise, axial displacement of tested panels was measured by placing two LVDTs along the height of the panel at each end, D15 to D16 in single panel and D19 to D20 in jointed ones. Also, strain gauges were mounted along the centre lines of the panels for measuring longitudinal strains on both compression (C) and tension (T) skin sides. The monitoring arrangement in single panels and in two jointed panels is shown in Fig. 4. Additionally, different views of the test setup are presented in Fig. 5.

\section{Results and analysis}

\section{Material characterization}

Tensile tests carried out on coupons of GFRP profiles and skins showed a linear-elastic behavior until failure. All of the tested specimens failed in a brittle manner, and the failure was localized at the middle part of the specimens. The obtained values for the ultimate tensile strength $\left(\sigma_{u}\right)$ and elastic modulus $(E)$ are listed in Table 1 (in both longitudinal and transverse directions in the coupons of GFRP skins).

The results obtained in the compression tests with samples of PU foam core showed response composed of three distinct phases: (i) a linear elastic branch followed by (ii) a plastic plateau with nearly constant stress, and (iii) a strain-hardening stage at large strains, with large compressive deformation (Fam and Sharaf 2010), which corresponds to the progressive densification of the material (Borsellino, et al. 2004). Shear tests performed with PU foam core coupons showed linear elastic behavior until failure, which was brittle, with the formation of failure surfaces at an angle of nearly $45^{\circ}$. In the case of tensile tests, performed 
Abdolpour, H.; Escusa, G.; Sena-Cruz, J.; Valente, I.; Barros, J. (2017) “Axial performance of jointed sandwich wall panels." Journal of Composites for Construction, 21(4): 040170091 04017009-12.

PU foam core coupons presented linear elastic behavior until failure. Slight strain hardening was noticed prior to failure of coupons. Table 1 lists the relevant results obtained on the PU foam core tests.

From the direct tensile tests performed on polyester resin specimens an ultimate tensile strength of $40 \mathrm{MPa}(\mathrm{CoV}=7.8 \%)$ and an ultimate tensile strain of $0.0259 \mathrm{~m} / \mathrm{m}(\mathrm{CoV}=3.1 \%)$ were obtained. In the pull-off test performed an ultimate tensile strength of $0.50 \mathrm{MPa}$ $(\mathrm{CoV}=18.7 \%)$ was obtained. The failure was observed in the PU foam core. No failure was detected in the interface between GFRP and PU foam core. Comparing ultimate tensile strength of polyester resin $(40 \mathrm{MPa})$ with the tensile strength value obtained from the pull-off test $(0.50 \mathrm{MPa})$ confirmed that the polyester resin had the capability of ensuring sufficient bond between GFRP skin and PU foam core. On the other hand, comparing ultimate tensile strength of PU foam core with the tensile strength value obtained by pull-off test showed that the values are similar, which supports the conclusion that the PU tensile failure occurred due to excessive out-of-plane tensile stress (Mousa and Uddin 2012).

\section{Assembly functionality and axial loading test results}

The functionality of the proposed system for connecting sandwich wall panels was noticed during the practical assembling process. Since the installation process was done without using any chemical adhesive for joining sandwich wall panels, the total process was relatively quick to perform. From the assembly of the prefabricated segments in a confined space, it could be concluded that this system was much more efficient than conventional methods.

The axial load versus mid height deflection of the tested single wall panels and jointed wall panels are plotted in the Fig. 6a and Fig. 6b, respectively. For the single wall panels, lateral deflection was obtained based on the average deflection registered in the three LVDTs 
Abdolpour, H.; Escusa, G.; Sena-Cruz, J.; Valente, I.; Barros, J. (2017) “Axial performance of jointed sandwich wall panels." Journal of Composites for Construction, 21(4): 040170091 04017009-12.

placed at mid height of the panels (D12-D14, Fig. 4a). In jointed panels, the lateral deflection was calculated based on the average measurement recorded by the six LVTDs installed at mid height of the panels (D13-D18, Fig. 4b).

Regarding the single wall panels, it is observed that the axial behavior of the single wall panel WP1 is similar to that of the single wall panel WP2, until failure. Axial load capacity of these specimens increased almost linearly until a load of $59 \mathrm{kN}$, at which a deflection of $4.5 \mathrm{~mm}$ was registered. A nonlinear response was noticed after this loading stage. Inspection of panels showed that GFRP skin in the compression side initiated debonding from the PU foam core. This kind of localized failure mode is well known as outward wrinkling failure of the sandwich panel. Increasing the load resulted in the progression of this nonlinearity, which is correlated to the debonding process. This localized failure led to buckling at an average load of $67 \mathrm{kN}$, when the deflection was $11.7 \mathrm{~mm}$. After this stage, due to local loss of stability of the GFRP skins and subsequently buckling of the panels, a structural softening was recorded.

Similar responses to the single wall panels were also observed in the case of the two jointed panels. The wall panels WP3+WP4 presented an axial load of $121 \mathrm{kN}$ and mid height deflection of $18.09 \mathrm{~mm}$ when the panels experienced outward buckling of GFRP skin on one side. Thereafter, the jointed panels continued to carry out the load, and at the maximum axial load of $128 \mathrm{kN}$ and mid height deflection of $35.61 \mathrm{~mm}$ the overall buckling has occurred with an extensive and abrupt increasing in lateral deflection and subsequently structural softening was recorded. Regarding to the jointed panels WP5+WP6, the GFRP outward buckling and overall buckling failure modes seem to have occurred at nearly the same time. The jointed panel captured the maximum axial load and mid height deflection by the values of $168 \mathrm{kN}$ and $3.01 \mathrm{~mm}$ respectively. At the peak load, jointed wall panels WP5+WP6 unexpectedly buckled out to the opposite direction of expected one causing the lake of measuring 
Abdolpour, H.; Escusa, G.; Sena-Cruz, J.; Valente, I.; Barros, J. (2017) “Axial performance of jointed sandwich wall panels." Journal of Composites for Construction, 21(4): 040170091 04017009-12.

displacements after this level of load. After failure of jointed wall panels WP5+WP6, all of the LVDTs were repositioned to measure the final mid height deflection. Consequently, data was not recorded in this period of time (failure and rearranging). The plateau observed in the load-lateral deflection curve is consequence of this problem.

The tests performed with the two jointed panels yielded significant differences between WP3+WP4 and WP5+WP6, in terms of ultimate load (of about 20\%) and failure mode (local versus global). The main reason for this behaviour is related to the actual geometry of the panels, in consequence of the hand-layup technique adopted by the supplier for the production of the panels. In spite of being an easy manufacturing technique, not requiring advanced and expensive equipment, present some disadvantages such as on ensuring a uniform geometry and material arrangement for the final product. Additionally, the level of complexity of the test setup was quite high due to i) the overall geometry of the specimens (of about $2.0 \mathrm{~m}$ of width by $3.0 \mathrm{~m}$ of height), ii) the system to apply the load (from the top), iii) the particularities of the supporting system of the specimens at both extremities, and iv) the difficulties of ensuring enough precise alignment of the jointed panels. Furthermore, some out-of-straightness geometric imperfection of the panels (WP3+WP4) introduced initial eccentricities which caused some of misalignment of the test setup and affected the behaviour of the panels.

Through the analysis of Fig. 6b, it appears that the jointed panels WP5+WP6 failed due to global buckling instability since failure occurred rapidly after initiation of the localized debonding between GFRP compression skin and PU foam core. These panels presented insignificant nonlinear behavior when compared to the WP3+WP4 jointed panels, which justifies the differences in the lateral displacement values at failure. 
Abdolpour, H.; Escusa, G.; Sena-Cruz, J.; Valente, I.; Barros, J. (2017) “Axial performance of jointed sandwich wall panels." Journal of Composites for Construction, 21(4): 040170091 04017009-12.

The results are indicated in Table 2. By comparing maximum axial load in the single wall panels with the jointed wall panels, it was observed that depending on the failure modes, axial capacity increased from $91 \%$ to $152 \%$.

The lateral deflection of each jointed panel at midspan was measured by two LVDTs placed at the center of each panels (D14 and D17). It was observed that, in the both jointed panels, nearly the same values were recorded by both LVDTs. In fact, in the WP3+WP4, at a load of $128 \mathrm{kN}$, the D14 and D17 registered the values of $36.10 \mathrm{~mm}$ and $36.01 \mathrm{~mm}$ respectively. Similarly, in WP5+WP6, at a load of $168 \mathrm{kN}$, D14 and D17 recorded the values of $3.10 \mathrm{~mm}$ and $3.05 \mathrm{~mm}$ respectively. These results confirm the efficiency of the connection for interconnecting two sandwich wall panels.

Since during the test setup of the jointed wall panels any monitoring of the joint system was applied, the behavior of the joint during loading was obtained from the visual inspection. No relative displacement between panels at joint was observed, which confirms the effectiveness of the jointing system adopted.

The axial displacements developed in each test for the buckling load are listed in Table 2. The axial displacements in all of the tested panels were calculated based on the average displacements of two LVDTs placed at the ends of the panels (D15-D16 for single panels and D19-D20 in jointed panels). Linear response was observed for load-axial displacements, and based on this response, axial stiffness of the panels was calculated as the slope of the curves. Accordingly, the average axial stiffness in the case of single and jointed sandwich wall panels was calculated, and the values of $2.8 \mathrm{kN} / \mathrm{mm}$ and $6.4 \mathrm{kN} / \mathrm{mm}$ were obtained, respectively, which is a factor of 2.28. Since the width of the jointed panels is twice that of the single wall panel, it indicates that the connector influenced the axial stiffness by a factor of 1.28. 
Abdolpour, H.; Escusa, G.; Sena-Cruz, J.; Valente, I.; Barros, J. (2017) “Axial performance of jointed sandwich wall panels." Journal of Composites for Construction, 21(4): 040170091 04017009-12.

Figures $7 \mathrm{a}$ and $7 \mathrm{~b}$ show the axial load versus longitudinal strains for single wall panels and jointed wall panels. The strain gauge on the compressive skin of WP1, did not function properly; however, for the remaining panels, the measured compression $(\mathrm{C})$ and tension $(\mathrm{T})$ strains are included. Regarding the jointed panels, the strain in the compression and tensile sides presented in Fig. $7 \mathrm{~b}$ is the average of the values recorded in the two applied strain gauges. From the data recorded in the strain gauges, it was noticed that both skins start with approximately equal compressive strains just below the localized failure load. Thereafter, the strains diverged nonlinearly, indicating significant bending and eminent failure. Once the failure occurred, strain gauges on the convex side of the deformed panel presented compression strains, while the strain gauges localized on the concave side of deformed panels showed tensile strains.

The efficiency of the proposed connection system for jointing sandwich wall panels was attested by comparing the registered strain gauges at the concave side of each deflected panels. It was noticed that, in the panels WP3+WP4, at a load level of $121 \mathrm{kN}$, values of 1205 and -1288 micro strains were recorded in the panels WP3 and WP4, respectively. Likewise, in the jointed panel WP5+WP6, at a load level of $168 \mathrm{kN}$, the panels WP5 and WP6 presented the values of -1164 and -1148 micro strains, respectively. Therefore, the differences between the two pairs of strains are negligible in both cases, which also supports the effectivity of the technique in adequately interlocking the two sandwich wall panels and, contributing for the monolithic nature of this wall system.

The maximum registered strains on the tension side of the single wall panel and of the two jointed wall panels $(0.0017 \mathrm{~m} / \mathrm{m}$ and $0.0015 \mathrm{~m} / \mathrm{m}$, respectively) were significantly lower than the ultimate tensile strain measured in GFRP skins $(0.0117 \mathrm{~m} / \mathrm{m})$ during skin material characterization. Thus, a direct conclusion could be drawn that during axial performance of 
Abdolpour, H.; Escusa, G.; Sena-Cruz, J.; Valente, I.; Barros, J. (2017) “Axial performance of jointed sandwich wall panels.” Journal of Composites for Construction, 21(4): 04017009 1 04017009-12. composite sandwich wall panels the material used in the GFRP skins was underutilized. Previously, (Fam and Sharaf, 2010) observed the same situation in sandwich panels tested in bending.

\section{Failure modes}

Failure modes of all tested panels are depicted in Fig. 8. All tested panels primarily failed by the localized instability of the skins, in the form of outward wrinkling of the GFRP skin at the compression side (convex side of the deflected panels). This mechanism can be explained by the occurrence of interfacial tensile stresses between GFRP skin and PU foam core that were higher than the ultimate tensile strength of PU foam core. This failure arose from the very soft nature of PU foam core and the relatively low tensile bond strength between the PU foam core and GFRP skin. Generally, a local failure was observed in the panel, localized at onethird of its height. Finally, localized failures mechanism, lead to an apparent overall buckling in all tested panels. It is worth mentioning that, the failure mechanisms in the jointed sandwich wall panels occurred in the sandwich wall panels and no damage was detected in the connector.

\section{Analytical study}

Consider a sandwich wall panel of height $L$, width $b$, and with simply supported boundary conditions at both ends (Fig. 9a) subjected to axial loading. The proposed panel has a skin thickness $t_{f}$, skin elastic modulus $E_{f}$, core thickness $t_{c}$, core elastic modulus and shear modulus, $E_{c}$ and $G_{c}$, respectively. 
Abdolpour, H.; Escusa, G.; Sena-Cruz, J.; Valente, I.; Barros, J. (2017) “Axial performance of jointed sandwich wall panels." Journal of Composites for Construction, 21(4): 040170091 04017009-12.

$412 \quad \frac{1}{P_{c r}}=\frac{1}{P_{E}}+\frac{1}{P_{s}}$ where $P_{E}$ is the Euler buckling load (based on bending moment), and $P_{s}$ is the localized

A strut was selected to evaluate behavior of the panel during the loading (Fig. 9b). It can be observed that sandwich wall panel started to buckle when the axial load acted on the panel reaches the critical buckling load $\left(P_{c r}\right)$. Due to this fact, significant lateral deflection in the panel occurred (Fig. 9c). At a cross section positioned at $y$ from the panel's extremity, two components could be considered for a resultant thrust, $P$. The first one is $P \sin (\theta)$ acting perpendicular to the middle surface of the panel representing a shear force, while the second one is $P \cos (\theta)$ that is tangent to this surface and imposes bending moments (Fig. 9d).

Consequently, two superimposed lateral deflections $\Delta_{1}$ and $\Delta_{2}$ were developed during buckling. The first one results from additional displacement associated with the shear deformation, while the second one is ordinary bending displacement.

\section{Global buckling load}

Based on those two deflections, $\Delta_{1}$ and $\Delta_{2}$, Allen (1969) proposed a general equation for calculating the critical global buckling load $\left(P_{c r}\right)$ in sandwich panels, as expressed by Eq. (1).

shear buckling load (based on shear force). Hence, in a sandwich panel with soft foam core, the critical buckling load is governed not only by the flexural stiffness of the panel but also by the shear stiffness of foam core. However, in panels with internal ribs, shear deformation of the core becomes negligible due to the relatively high shear stiffness ensured by GFRP ribs; thus, Euler load will be the dominant buckling load (Allen 1969, Carlsson and Kardomateas 2011, Mathieson and Fam 2015). 
Abdolpour, H.; Escusa, G.; Sena-Cruz, J.; Valente, I.; Barros, J. (2017) “Axial performance of jointed sandwich wall panels.” Journal of Composites for Construction, 21(4): 04017009 1 04017009-12.

$423 \quad P_{E}=\frac{\pi^{2} \times(E I)_{e q} .}{L^{2}}$ ribs in wall panels.

where $(E I)_{e q}$. is the equivalent flexural stiffness of the panel. Since the cross section

425

In this study, the Euler buckling load is considered the critical buckling load, since the two GFRP ' $U$ ' profiles placed in the longitudinal direction of the panel at its extremities act as

proposed in this study for the sandwich wall panel was symmetric, the neutral axis is placed at the middle-surface of the panel and then the equivalent flexural stiffness of the wall section is represented by Eq. (3)

$(E I)_{e q .}=b E_{f}\left[\frac{t_{f}{ }^{3}}{6}+2 t_{f}\left(\frac{t_{f}}{2}+\frac{t_{c}}{2}\right)^{2}\right]+n E_{U} \frac{t_{U} t_{c}{ }^{3}}{12}$

where $n, E_{U}$ and $t_{U}$ are, respectively, the number, the elastic modulus and the thickness of the GFRP ' $U$ ' profiles.

\section{Skin wrinkling of sandwich wall panels}

\section{Interfacial tensile stress}

During axial testing, local buckling failure occurred due to debonding of the GFRP skins in the compression side of the deflected sandwich wall panels. This particular instability of the GFRP skins corresponds to a wrinkling effect in which the GFRP skin buckled towards the outside in a sinusoidal shape, with half wave length $\left(L_{h}\right)$ equal to the debonded part (see Fig. 10). It is worth mentioning that previous investigations (Allen 1969, Southward, et al. 2008) demonstrated that $L_{h}$ is the same order as the thickness of PU foam core $\left(t_{c}\right)$. 
Abdolpour, H.; Escusa, G.; Sena-Cruz, J.; Valente, I.; Barros, J. (2017) “Axial performance of jointed sandwich wall panels.” Journal of Composites for Construction, 21(4): 04017009 1 04017009-12.

440 Based on the Winkler Elastic Foundation (WEF) approach, Allen (1969) assumed that the

$447 \quad w=w_{m} \sin \frac{\pi x}{L_{h}}$ compressed GFRP skin could be modelled by a strut supported on an elastic foundation PU foam core. A set of closely-spaced springs were adopted to simulate the behavior of an elastic foundation corresponding to the foam core. A fourth order differential equation was proposed in Eq. (4) and Eq. (5) to take into account the sinusoidal waves with half wavelength developed when the compression face skin buckles.

$D \frac{d^{4} w}{d y^{4}}+P \frac{d^{2} w}{d y^{2}}=b\left(\sigma_{\text {inter }}\right)$

where $D$ is the flexural stiffness of the strut, $P$ is the axial thrust in the strut, $w$ is the displacement, $\sigma_{\text {inter }}$ is the interfacial stress and $w_{m}$ is the maximum displacement. By substituting Eq. (5) in Eq. (4) and differentiating this latter equation, it was possible to obtain the interfacial stress, as defined by Eq. (6). The first part of this equation is the stiffness of the assumed springs in the WEF approach, as previously proposed by Mousa and Uddin (Mousa and Uddin 2012), and the second part represents the sinusoidal displacement at the compressed GFRP skin.

$\sigma_{\text {inter }}=\left[E_{c} t_{c}\left(\frac{\pi}{L_{h}}\right)^{2} f(\theta)\right] \cdot\left[w_{m} \sin \frac{\pi x}{L_{h}}\right]$

where $L_{h}$ is the half wave length and $f(\theta)$ is the skin wrinkling mode shape. Three cases of skin wrinkling failure modes are defined in Fig. 11. Case I corresponds to rigid base or single sided, case II deals with antisymmetric wrinkling, and case III considers symmetric wrinkling. In this research, case I was considered the most appropriate since only one face 
Abdolpour, H.; Escusa, G.; Sena-Cruz, J.; Valente, I.; Barros, J. (2017) “Axial performance of jointed sandwich wall panels.” Journal of Composites for Construction, 21(4): 04017009 1 04017009-12.

460

461

462

463

464

465

466

467

468

469

470

where $v_{c}$ is the Poisson's ratio of the PU foam core and $\theta$ is the function of core thickness and half wave length, as given by Eq.(8).

$\theta=\frac{\pi t_{c}}{L_{h}}$

\section{Critical wrinkling stress}

The second stress associated with wrinkling failure modes in compressed GFRP skins is the critical in-plane compressive wrinkling stress $\left(\sigma_{c r}\right)$, which can be obtained from Eq. (9). This stress is calculated based on the aforementioned Winkler Elastic Foundation (WEF) approach. Complementary information can be found elsewhere (Allen 1969, Mousa and

Uddin 2012)

$\sigma_{c r}=\beta_{1} E_{s}^{1 / 3} E_{c}^{2 / 3}$

$\beta_{1}=\frac{\rho^{2} \theta^{2}}{12}+\frac{f(\theta)}{\rho}$

$\rho=\frac{t_{f}}{t_{c}}\left[\frac{E_{f}}{E_{c}}\right]^{1 / 3}$

where $\rho$ is a coefficient depending on the elastic modulus and thickness of the GFRP skin and PU foam core. By comparing Eq. (9), used to calculate the critical wrinkling stress, with 
Abdolpour, H.; Escusa, G.; Sena-Cruz, J.; Valente, I.; Barros, J. (2017) “Axial performance of jointed sandwich wall panels." Journal of Composites for Construction, 21(4): 040170091 04017009-12.

Eq. (6), adopted to determine interfacial tensile stress, it was noticed that critical wrinkling stress is evidently dependent on the material properties of GFRP skin and foam core, while interfacial tensile stress only depends on the foam core material properties.

Based on the critical wrinkling stress calculated on the compression GFRP face skin, an equation was suggested (Mousa and Uddin 2012) to determine its corresponding critical buckling load:

$P_{c r-w r i n k l i n g}=\sigma_{c r} b t_{f}$

Substituting Eq. (9) into Eq. (12) results in a general form of the critical buckling load:

$$
P_{c r-w r i n k l i n g}=\beta_{1}\left(E_{f}^{1 / 3} E_{c}^{2 / 3}\right) b t_{f}
$$

\section{Validation of model based on experimental results}

\section{Global buckling in sandwich panels}

Based on Eq. (3), a flexural stiffness of $63.0 \mathrm{kN} \cdot \mathrm{m}^{2}$ was obtained in the single wall panels. Substituting this result in Eq. (2) led to an Euler buckling load of $74.96 \mathrm{kN}$. It is clear that the analytical prediction differs from the experimental result $(67 \mathrm{kN})$. This difference (about $12 \%$ ) could be explained by the wall panel failure mode in axial loading, since both single panels failed due to local buckling instability, while the analytical Eq. (2) is only applicable when a global Euler instability occurs. Therefore, the loads corresponding to the interfacial tensile stress and critical wrinkling stress should be evaluated.

Concerning the jointed wall panels system, a flexural stiffness of $143.83 \mathrm{kN} \cdot \mathrm{m}^{2}$ was obtained from Eq. (3). Substituting this value in Eq. (2) led to a global buckling load of $171.15 \mathrm{kN}$. By comparing this value with the Euler buckling load obtained in the single wall 
Abdolpour, H.; Escusa, G.; Sena-Cruz, J.; Valente, I.; Barros, J. (2017) “Axial performance of jointed sandwich wall panels." Journal of Composites for Construction, 21(4): 040170091 04017009-12.

panel $(74.96 \mathrm{kN})$, it can be seen that these two values differ by a factor of 2.28 . Since the total width of the jointed wall panels is twice that of the single wall panel, it is concluded that the presence of a connector led to an increase in the global buckling load by a factor of 1.28. Recalling the experimental axial loads of $128 \mathrm{kN}$ (WP3+WP4) and $168 \mathrm{kN}$ (WP5+WP6), it was observed that the load carrying capacity the first connected jointed panels (WP3+WP4) differed significantly from the analytically predicted ones, while this difference was less pronounced, as expected, in the second jointed panels (W5+W6). This fact can be explained by the observed failure modes. The dominant failure mode in the (WP3+WP4) was due to local buckling instability, while in the (WP5+WP6) the dominant failure mode was the global Euler buckling.

\section{Skin wrinkling of sandwich wall panels}

Interfacial tensile stress was calculated based on Eq. (6) and was used to compute the maximum out-of-plan tensile stress between the GFRP skin and the foam core, in order to evaluate the debonding between these two materials. The values of $f(\theta)$ and $\theta$ were determined based on Eq. (7) and Eq. (8) and the values of 0.18 and 3.14 were obtained. An interfacial stress value of $0.78 \mathrm{MPa}$ was obtained by substituting these values into Eq. (6). Comparing this value with the maximum tensile stress of PU foam core (see Table 1) displayed that the main reason for debonding failure mode could be explained by exceeding the interfacial tensile stress between GFRP skin and PU foam core from ultimate tensile strength of PU foam core. This was also observed in previous investigation work where the same failure mode was registered ( Mousa and Uddin 2012). It is worth mentioning that interfacial tensile stress was independent of wall panel's geometry, therefore the same value is attained in the single panel and in the two jointed panels. 
Abdolpour, H.; Escusa, G.; Sena-Cruz, J.; Valente, I.; Barros, J. (2017) “Axial performance of jointed sandwich wall panels." Journal of Composites for Construction, 21(4): 040170091 04017009-12.

\section{Critical wrinkling load}

Eq. (13) was used to predict the critical load of both the single sandwich wall panels and the jointed wall panels. In this equation the variables $E_{f}, E_{c}, t_{f}, t_{c}, b$ (in single wall panel) and $b$ (in two jointed wall panels) were substituted by the values of $9600 \mathrm{MPa}, 5 \mathrm{MPa}$, $2 \mathrm{~mm}, 60 \mathrm{~mm}, 960 \mathrm{~mm}$ and $1920 \mathrm{~mm}$, respectively. Coefficient $\beta_{1}$ was calculated according to the Eq. (10), having obtained a value of 0.59 .

Using Eq. (13) resulted in the values of $69.20 \mathrm{kN}$ and $138.40 \mathrm{kN}$ for the single wall panel and jointed wall panels, respectively. In the experimental program an average axial load of $66.75 \mathrm{kN}$ for single panels (WP1 and WP2) and 127. $078 \mathrm{kN}$ for jointed panels (WP3+WP4) was obtained. The comparison between these values and the analytical ones showed that Eq. (13) is quite precise in predicting the panels axial load capacity when a wrinkling failure mode occurs. Jointed wall panel WP5+WP6 was not taken into account in this comparison since this jointed panel developed a global buckling failure mode.

Additionally, by comparing the results experimentally obtained in single wall panels and in two jointed wall panels, it can be observed that these two values differ by a factor of 1.91 . This result shows that connecting panels by the proposed techniques increased the critical wrinkling load nearly twice in comparison to single wall panels, demonstrating the high effectiveness of the proposed technique.

\section{Conclusion}

This paper has presented and evaluated the effectiveness of a novel connection system for joining sandwich wall panels. The proposed wall system was designed to be used as insulated wall elements in buildings, more specifically in a prefabricated modular system. The 
Abdolpour, H.; Escusa, G.; Sena-Cruz, J.; Valente, I.; Barros, J. (2017) “Axial performance of jointed sandwich wall panels." Journal of Composites for Construction, 21(4): 040170091 04017009-12.

capability of rapid on-site assembly/disassembly and ease of integration in the production line could be mentioned as advantages, achieved by the proposed wall system comprising GFRP skins, PU foam core and connectors. GFRP pultruded ' $U$ ' shaped profiles were positioned along each edge of the panel and were considered as connectors. Some important conclusions can be drawn from the developed work:

1. Using the proposed connection and the light-weight nature of structural members, the assembly of the wall panels was performed easily. As such, this system presents a high potential to be used as wall elements in prefabricated dwellings or in the building sector.

2. Linear elastic response of wall panels was observed, prior to failure, in all the tested wall panels, through the analysis of load-mid height deflection and load-axial displacement curves.

3. Mounted strain gauges in both sides of the skins exhibited similar behavior before failure, due to axial compression of the GFRP skins. After initiation of failure, the strain gauges positioned in the convex side and in the concave side of the deformed panels presented compressive and tensile behavior, respectively. The maximum tensile strain registered in the GFRP skin was $14 \%$ of the ultimate tensile strain of this composite material. This represents that during axial loading of sandwich wall panels the material used for the GFRP skins is somewhat underutilized.

4. Three modes of failure were observed in single wall panels and in two jointed wall panels. The panels first started to show a localized failure at GFRP skin in the compression side. This localized failure corresponds to the instability of the GFRP skin in a half wave length that is equal to the core thickness. The second failure mode was related to the propagation of this failure towards the GFRP skin and the PU core due to the load increase. Finally, all the panels failed due to global instability of the 
Abdolpour, H.; Escusa, G.; Sena-Cruz, J.; Valente, I.; Barros, J. (2017) “Axial performance of jointed sandwich wall panels." Journal of Composites for Construction, 21(4): 040170091 04017009-12. system that resulted from the degradation of integrity between GFRP skins and foam core;

5. In the jointed panels, disparities in ultimate load (of about 20\%) and failure modes (local versus global) were triggered by initial eccentricity in one of the jointed panels during the loading process. The main reasons for this eccentricity are related to the actual geometry of the panels and the level of complexity of the test setup.

6. Regarding to the theoretical study, a reasonable agreement between experimental results and theoretical predictions were observed in both failed panels due to global buckling and due to localized wrinkling buckling. It was concluded that in global buckling failure of jointed panels, axial load increased by a factor of 2.52 of the buckling failure load obtained in single wall panels. The presence of the connector was able to increase the global buckling load by a factor of 1.28 . However, it was also verified that the axial load capacity of jointed panels that suffered localized GFRP skin wrinkling failure was nearly 2.0 times higher than the corresponding failure load measured in single wall panels.

7. Finally, two kinds of stresses, namely interfacial out-of-plane stress and critical wrinkling stress were evaluated in this study. It was shown that high interfacial outof-plane stresses between PU foam core and GFRP skins occur, and that these stress values were higher than the tensile strength of the PU foam, resulting in debonding in both single and jointed panels. The calculated critical wrinkling stresses were in good agreement with the experimental values measured in both single and jointed panels.

\section{Acknowledgements}

This work is part of the research project ClickHouse - Development of a prefabricated emergency house prototype made of composites materials, involving the company ALTO Perfis Pultrudidos, Lda., CERis/Instituto Superior Técnico and ISISE/University of Minho, 
Abdolpour, H.; Escusa, G.; Sena-Cruz, J.; Valente, I.; Barros, J. (2017) “Axial performance of jointed sandwich wall panels.” Journal of Composites for Construction, 21(4): 04017009 1 04017009-12.

supported by FEDER funds through the Operational Program for Competitiveness Factors -

COMPETE and the Portuguese National Agency of Innovation (ADI) - project no. 38967.

Special thanks are given to company ALTO who manufactured all the elements (GFRP profiles and sandwich panels) involved in this work.

\section{References}

Allen, G. H. (1969). Analysis and Design of Structural Sandwich Panels. , Pergmon Press, London.

ASTM (2000a). "Standard Test Method for Tensile Properties of Polymer Matrix Composite Materials." ASTM D3039/D3039M-14, West Conshohocken, PA 19428-2959, United States.

ASTM (2000b). "Standard Test Method for Shear Properties of Sandwich Core Materials." ASTM C273, West Conshohocken, PA 19428-2959, United States.

ASTM (2004). "Standard Test Method for Tensile Properties of Plastics." ASTM D638, West Conshohocken, Pennsylvania 19428-2959, United States.

ASTM (2005a). "Standard Test Method for Flatwise Compressive Properties of Sandwich Cores." ASTM C365, West Conshohocken, PA 19428-2959, United States.

ASTM (2005b). "Standard Test Method for Tensile Strength of Concrete Surfaces and the Bond Strength or Tensile Strength of Concrete Repair and Overlay Materials by Direct Tension (Pull-off Method) " ASTM C1583, West Conshohocken, PA 19428-2959, United States.

ASTM (2006). "Standard Test Methods for Constituent Content of Composite Materials." ASTM D 3171-06, West Conshohocken, PA 19428-2959,, United States.

ASTM (2010). "Standard Test Method for Flatwise Tensile Strength of Sandwich Constructions." ASTM C297-04, West Conshohocken, PA 19428-2959, United States.

Borsellino, C., Calabrese, L., and Valenza, A. (2004). "Experimental and numerical evaluation of sandwich composite structures." Composites Science and Technology, 64(10-11), 1709-1715.

Carlsson, L. A., and Kardomateas, G. A. (2011). Structural and Failure Mechanics of Sandwich Composites, Springer, New York

Engesser, F. (1981). "Die Knickfestigkeit gerader St be." Zeitschrift des Architekten und Ingenieure Vereines zu Hannove, 35, 455.

Fam, A., and Sharaf, T. (2010). "Flexural performance of sandwich panels comprising polyurethane core and GFRP skins and ribs of various configurations." Composite Structures, 92(12), 2927-2935.

Frostig, Y. (1998). "Buckling of sandwich panels with a flexible core-high-order theory." International Journal of Solids and Structures, 35(3-4), 183-204. 
Abdolpour, H.; Escusa, G.; Sena-Cruz, J.; Valente, I.; Barros, J. (2017) "Axial performance of jointed sandwich wall panels." Journal of Composites for Construction, 21(4): 04017009 1 04017009-12.

Frostig, Y., and Barnch, M. (1993). "High-order buckling analysis of sandwich beams with transversely flexible core." Journal of Engineering Mechanics, 119(3), 476-495.

Garrido, M., Correia, J. R., Keller, T., and Branco, F. A. (2015). "Adhesively bonded connections between composite sandwich floor panels for building rehabilitation." Composite Structures, 134, 255-268.

Haringx, J. A. (1948). "On Highly Compressible Helical Springs and Rubber Rods, and Their Application for Vibration-Free Mountings, I." Phillips Research Reports,Eindhoven, the Netherlands, 3, 401-449.

Hart-Smith, L. J. (1973). "Advanced -Bonded Scarf and Stepped-Lap joints ", National aeronautics and space administration Virginia

Hart-Smith, L. J. (2003). "Adhesively Bonded Joints for Fibrous Composite Structures." Recent Advances in Structural Joints and Repairs for Composite Materials, L. Tongand C. Soutis, eds., Springer Netherlands, 173-210.

Keller, T., Rothe, J., de Castro, J., and Osei-Antwi, M. (2014). "GFRP-Balsa Sandwich Bridge Deck: Concept, Design, and Experimental Validation." J. Compos. Constr, 18(2), 04013043.

Liu, Z., Majumdar, P., Cousins, T., and Lesko, J. (2008). "Development and Evaluation of an Adhesively Bonded Panel-to-Panel Joint for a FRP Bridge Deck System." J. Compos. Constr, 12(2), 224-233.

Mara, V., Al-Emrani, M., and Haghani, R. (2014). "A novel connection for fibre reinforced polymer bridge decks: Conceptual design and experimental investigation." Composite Structures, 117, 83-97.

Mathieson, H., and Fam, A. (2015). "Axial Loading Tests and Simplified Modeling of Sandwich Panels with GFRP Skins and Soft Core at Various Slenderness Ratios." $J$. Compos. Constr., 19(2), 04014040.

Mousa, M. A., and Uddin, N. (2012). "Structural behavior and modeling of full-scale composite structural insulated wall panels." Engineering Structures, 41(0), 320-334.

Sharaf, T., Shawkat, W., and Fam, A. (2010). "Structural performance of sandwich wall panels with different foam core densities in one-way bending." Journal of Composite Materials, 44(19), 2249-2263.

Shawkat, W., Honickman, H., and Fam, A. (2008). "Investigation of a novel composite cladding wall panel in flexure." Journal of Composite Materials, 42(3), 315-330.

Southward, T., Mallinson, G. D., Jayaraman, K., and Horrigan, D. (2008). "Buckling of Disbonds in Honeycomb-core Sandwich Beams." Journal of Sandwich Structures and Materials, 10(3), 195-216.

Turner, M. K., Harries, K. A., Petrou, M. F., and Rizos, D. (2004). "In situ structural evaluation of a GFRP bridge deck system." Composite Structures, 65(2), 157-165.

Zhou, A., and Keller, T. (2005). "Joining techniques for fiber reinforced polymer composite bridge deck systems." Composite Structures, 69(3), 336-345.

\section{List of Tables}


Abdolpour, H.; Escusa, G.; Sena-Cruz, J.; Valente, I.; Barros, J. (2017) “Axial performance of jointed sandwich wall panels." Journal of Composites for Construction, 21(4): 04017009 1 04017009-12.

673 Table 1. Mechanical properties of constituent materials (mean values).

674 Table 2. Main results from the axial loading tests. 
Abdolpour, H.; Escusa, G.; Sena-Cruz, J.; Valente, I.; Barros, J. (2017) “Axial performance of jointed sandwich wall panels." Journal of Composites for Construction, 21(4): 04017009 1 04017009-12.

676

Table 3. Mechanical properties of constituent materials (mean values).

\begin{tabular}{lllll}
\hline GFRP & \multicolumn{1}{c}{$\sigma_{\max , \mathrm{L}}(\mathrm{MPa})$} & \multicolumn{1}{c}{$\sigma_{\max , T}(\mathrm{MPa})$} & $E_{L}(\mathrm{GPa})$ & $E_{T}(\mathrm{GPa})$ \\
\cline { 2 - 4 } GFRP profiles & $327.0(9.0 \%)$ & $2330(7.6 \%)$ & $32.0(6.5 \%)$ & $16.10(8.9 \%)$ \\
GFRP skin & $117.0(10.4 \%)$ & $117.0(24.7 \%)$ & $9.6(7.4 \%)$ & $10.3(8.0 \%)$ \\
\hline Foam & $\sigma_{\max }(\mathrm{MPa})$ & $E(\mathrm{MPa})$ & $G(\mathrm{MPa})$ & \\
\cline { 2 - 4 } Compression test & $0.30(10.0 \%)$ & $5.0(9.0 \%)$ & $3.15(12.1 \%)$ & \\
Tensile test & $0.49(8.9 \%)$ & & & \\
Shear test & $0.15(10.2 \%)$ & & & \\
\hline Other tests & $\sigma_{\max }(\mathrm{MPa})$ & $\varepsilon_{\max }(\mathrm{mm} / \mathrm{mm})$ & & \\
Polyester- tensile test & $40.4(7.8 \%)$ & $0.0259(3.1 \%)$ & & \\
Pull-off test & $0.5(18.7 \%)$ & & & \\
\hline & & &
\end{tabular}

$L:$ longitudinal direction, $T$ : transversal direction

The values between parentheses are the corresponding coefficients variation

678

679

680

681

682

683

684

685

686

687

688

689

690

691

692

693

694

695

696

697

698

699

700 
Abdolpour, H.; Escusa, G.; Sena-Cruz, J.; Valente, I.; Barros, J. (2017) “Axial performance of jointed sandwich wall panels.” Journal of Composites for Construction, 21(4): 04017009 1 04017009-12.

701

Table 4. Main results from the axial loading tests. 702

\begin{tabular}{|c|c|c|c|c|c|c|c|c|}
\hline \multirow{2}{*}{ Specimen } & \multirow{2}{*}{ Maximum load (kN) } & \multicolumn{5}{|c|}{ Lateral deflection at different levels (mm) } & \multicolumn{2}{|c|}{ Axial displacement } \\
\hline & & 0 & $h / 4$ & $h / 2$ & $3 h / 4$ & $h$ & $(\mathrm{~mm})$ & 703 \\
\hline WP1 & 68.0 & 2.64 & 6.50 & 10.99 & 7.47 & 5.16 & 23.10 & \\
\hline WP2 & 66.0 & 6.67 & 11.03 & 12.54 & 6.48 & 1.19 & 23.76 & 704 \\
\hline WP3+WP4 & 128.0 & 8.62 & 24.32 & 35.61 & 25.06 & 6.16 & 21.35 & \\
\hline WP5+WP6 & 168.0 & 1.95 & 1.38 & 3.01 & 2.45 & 1.06 & 24.13 & 705 \\
\hline
\end{tabular}

706

707

708

709

710

711

712

713

714

715

716

717

718

719

720

721

722

723

724

725

726

727

728

729

730

731 
Abdolpour, H.; Escusa, G.; Sena-Cruz, J.; Valente, I.; Barros, J. (2017) “Axial performance of jointed sandwich wall panels." Journal of Composites for Construction, 21(4): 040170091 04017009-12.

\section{List of figures}

Fig. 1. Various types of the jointing sandwich panels techniques: (a) Z-shaped; (b) stepped lap joint; (c) scarf joint; (d) male-female; (e) tongue and groove; (f) current proposal

.Fig. 2. Schematic of sandwich wall panels: (a) common sandwich wall panel; (b) Sandwich wall panel with sub-connector GFRP 'U' profiles; (c) sandwich wall panel with longitudinal and transversal GFRP 'U' profile and GFRP tubular connector; (d) longitudinally adjoining wall panels; (e) adjoining panels together and into beam element.

Fig. 3. Axial loading test setup: (a) overall test setup; (b) schematic representation; (c) detailing; (d) detail 1.

Fig. 4. Monitoring system: (a) single panel; (b) two jointed panels.

Fig. 5. Test setup for single panel and two jointed panels.

Fig. 6. Axial load vs. mid height lateral deflection: (a) single panel; (b) two jointed panels.

Fig. 7. Load vs. axial strain: (a) single panel compressive strain; (b) two adjusted panels.

Fig. 8. Failure modes observed in axially loaded single panel and two jointed panels.

Fig. 9. Axially loaded wall panel: (a) schematic of axially loaded panels; (b) strut subjected to axial load; (c) deformed shape of strut and (d) free body diagram of the bucked strut.

Fig. 10. GFRP skin wrinkling model and stresses.

Fig. 11. Principal types of wrinkling instability: (I) rigid base; (II) antisymmetric wrinkling and (III) symmetric wrinkling (Allen 1969). 
Abdolpour, H.; Escusa, G.; Sena-Cruz, J.; Valente, I.; Barros, J. (2017) “Axial performance of jointed sandwich wall panels.” Journal of Composites for Construction, 21(4): 04017009 1 04017009-12.

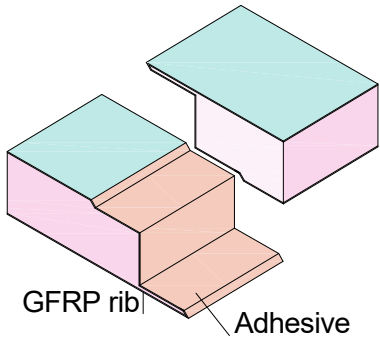

(a)

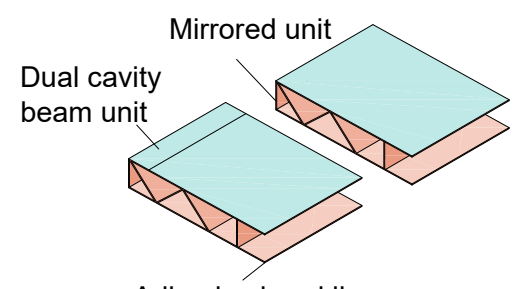

Adhesive bond line

(d)

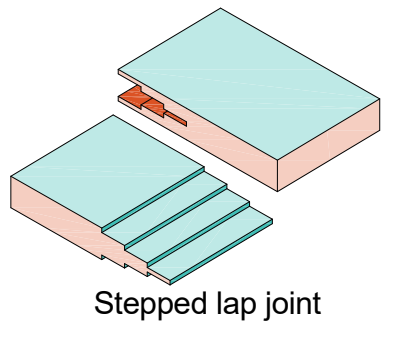

(b)

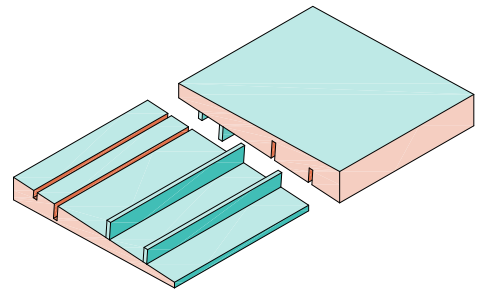

(e)

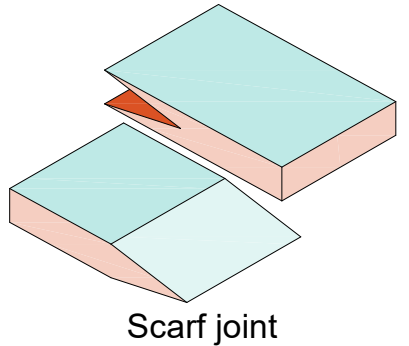

(c)

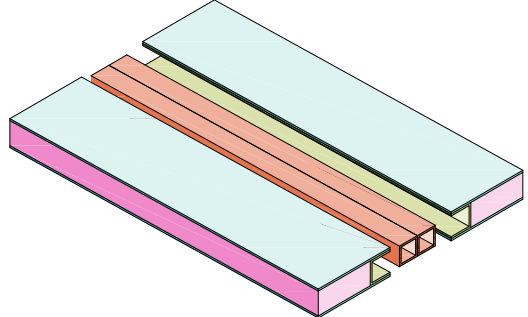

(f)

Fig. 12. Various types of the jointing sandwich panels techniques: (a) Z-shaped; (b) stepped lap joint; (c) scarf joint; (d) male-female; (e) tongue and groove; (f) current proposal. 


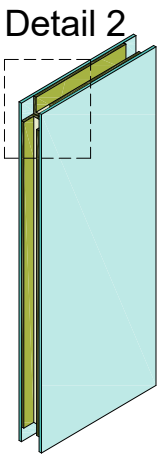

(a)

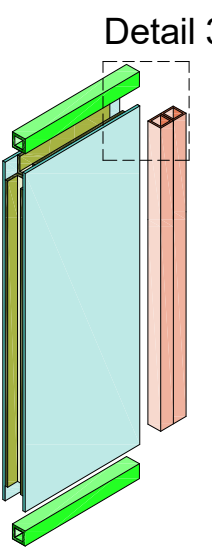

(c)

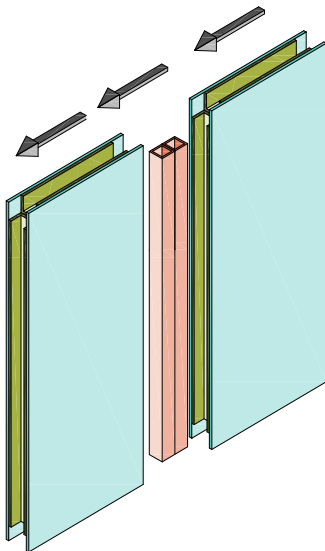

(d)

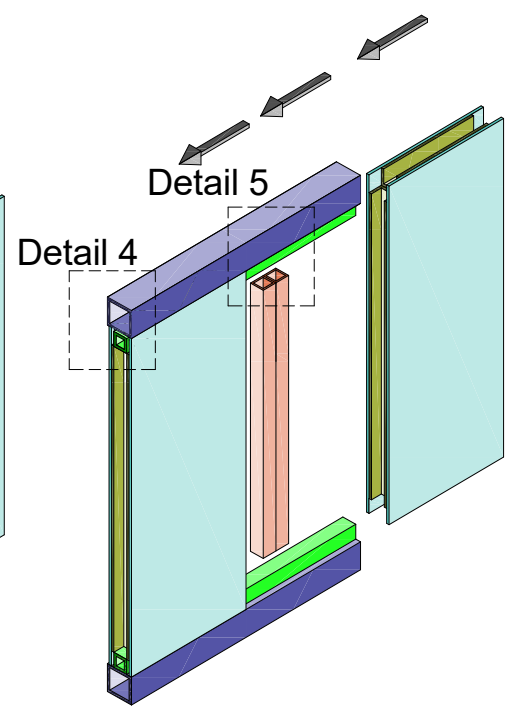

(e)

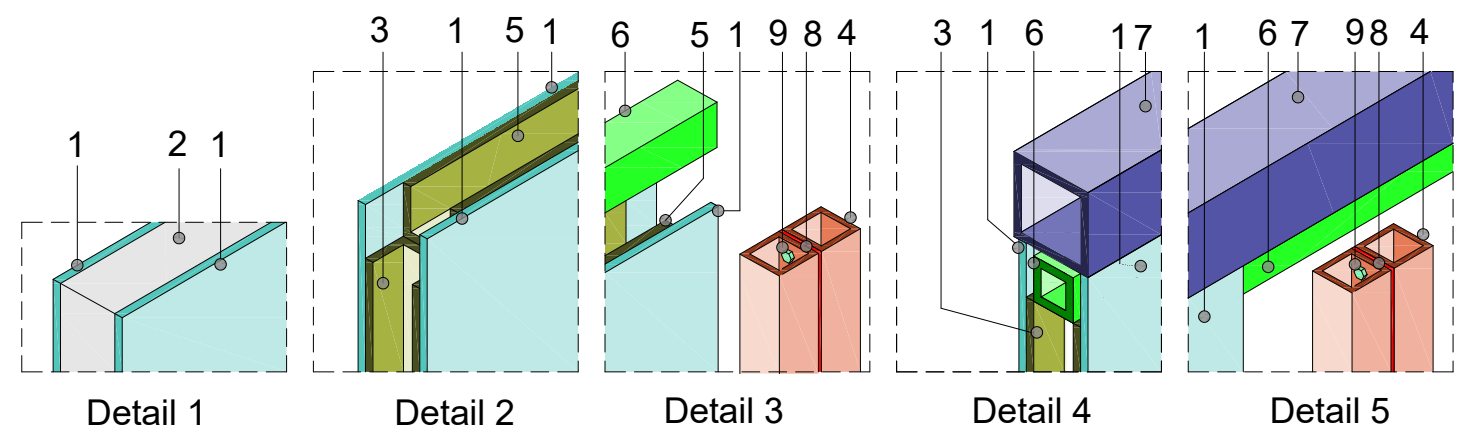

Legend: (1) GFRP skin; (2) foam core; (3) longitudinal GFRP U profile; (4) longitudinal GFRP tubular connector; (5) transversal GFRP U profile; (6) transversal GFRP tubular connector; (7) beam element; (8) adhesive layer; (9) M8 steel bolt; Note: the geometry of the sandwich wall panels is $2880 \times 960 \times 64 \mathrm{~mm}^{3}$.

Fig. 13. Schematic of sandwich wall panels: (a) common sandwich wall panel; (b) Sandwich wall panel with sub-connector GFRP U profiles; (c) sandwich wall panel with longitudinal and transversal GFRP U profile and GFRP tubular connector; (d) longitudinally adjoining wall panels; (e) adjoining panels together and into beam element. 
Abdolpour, H.; Escusa, G.; Sena-Cruz, J.; Valente, I.; Barros, J. (2017) “Axial performance of jointed sandwich wall panels." Journal of Composites for Construction, 21(4): 040170091 04017009-12.

766

767

768

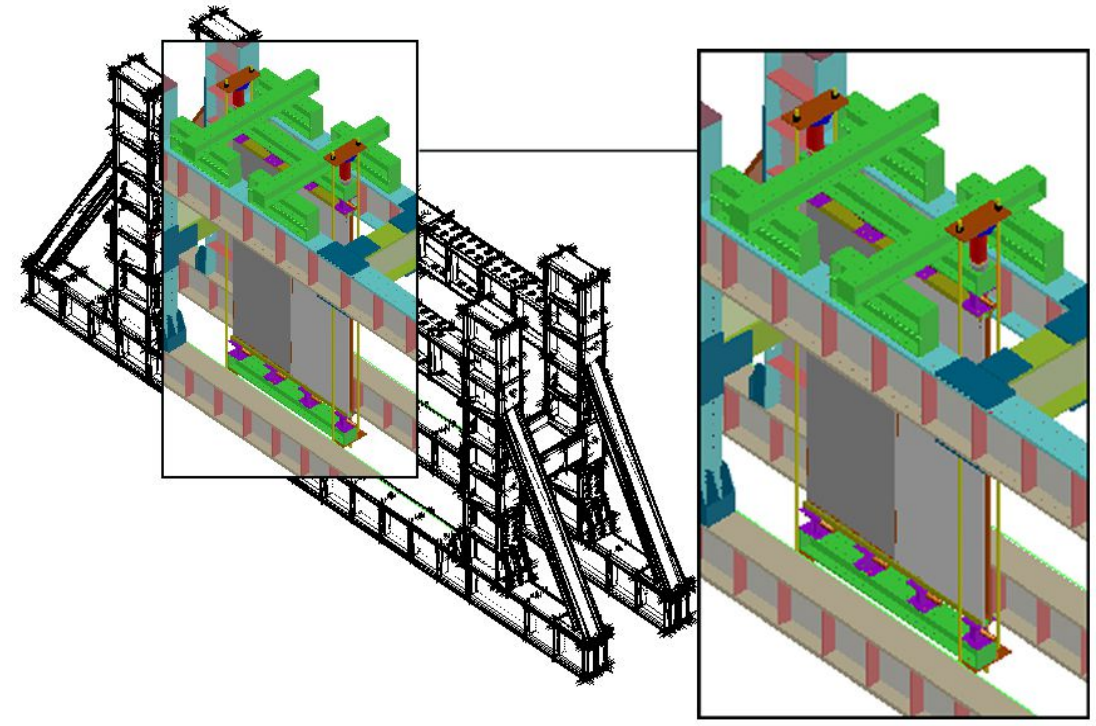

(a)

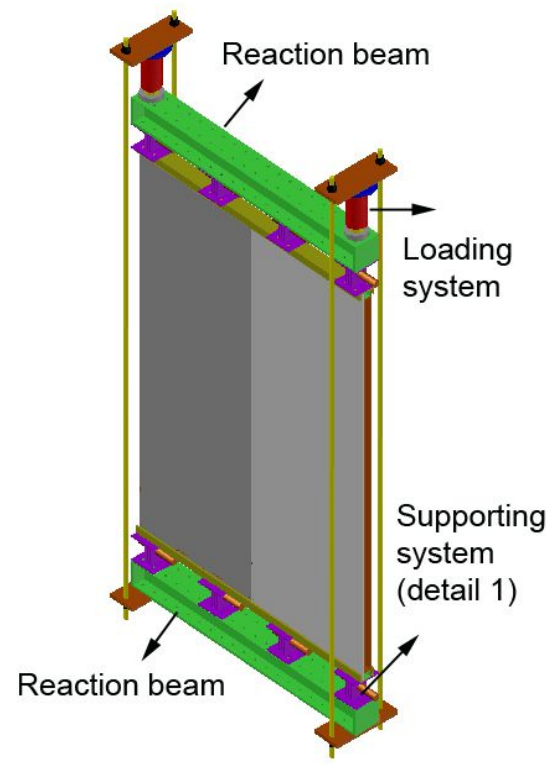

(b)

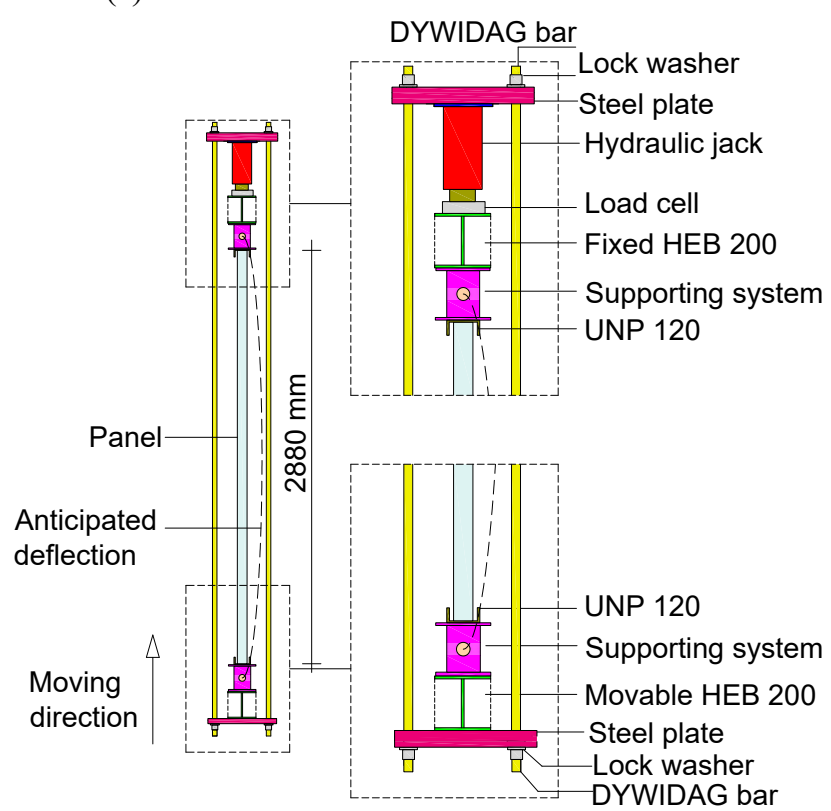

(c)

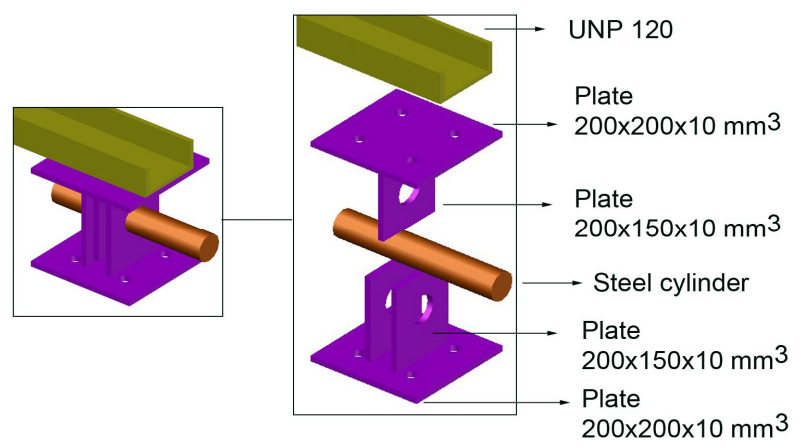

(d)

Fig. 14. Axial loading test setup: (a) overall test setup; (b) schematic representation; (c) detailing; (d) detail 1. 
Abdolpour, H.; Escusa, G.; Sena-Cruz, J.; Valente, I.; Barros, J. (2017) “Axial performance of jointed sandwich wall panels.” Journal of Composites for Construction, 21(4): 04017009 1 04017009-12.

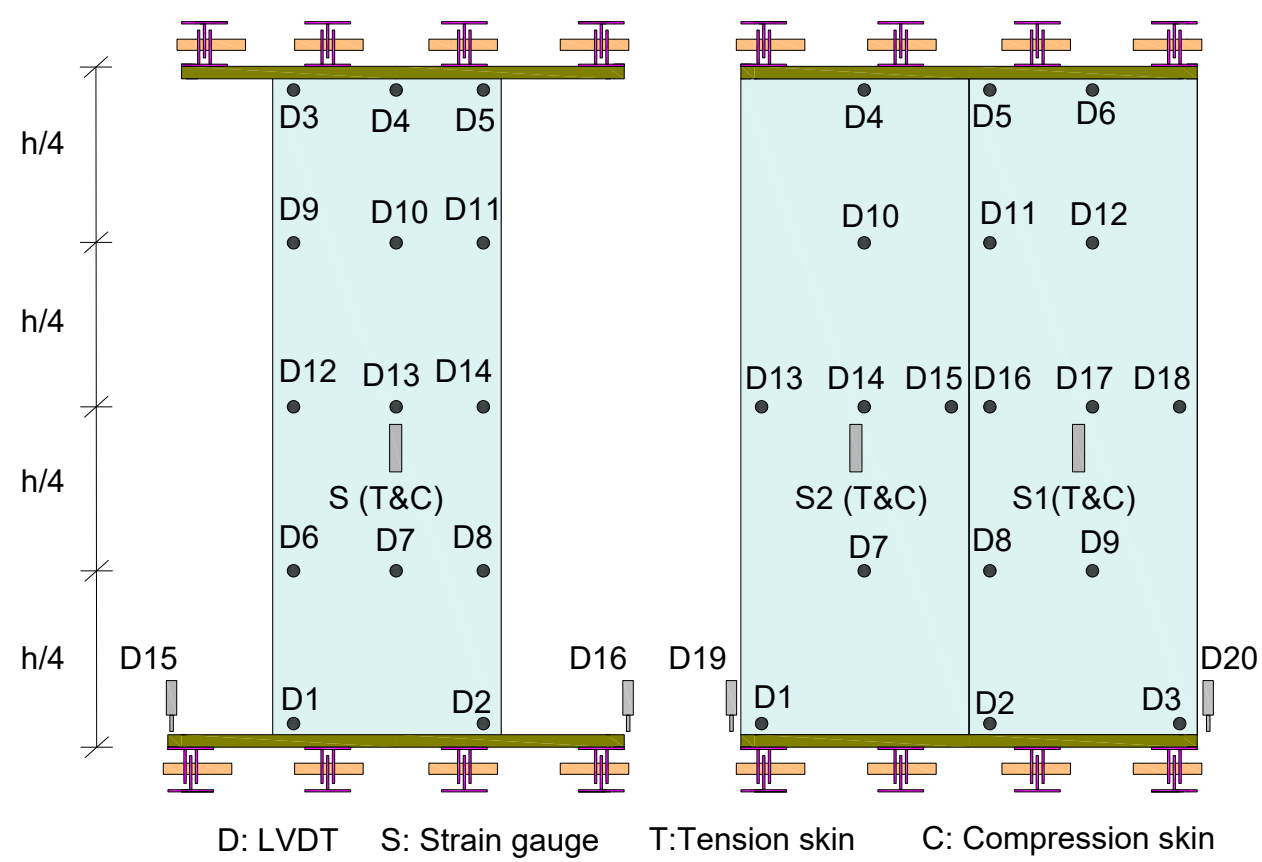

(a)

(b)

Fig. 15. Monitoring system: (a) single panel; (b) two jointed panels. 
Abdolpour, H.; Escusa, G.; Sena-Cruz, J.; Valente, I.; Barros, J. (2017) “Axial performance of jointed sandwich wall panels." Journal of Composites for Construction, 21(4): 04017009 1 04017009-12.
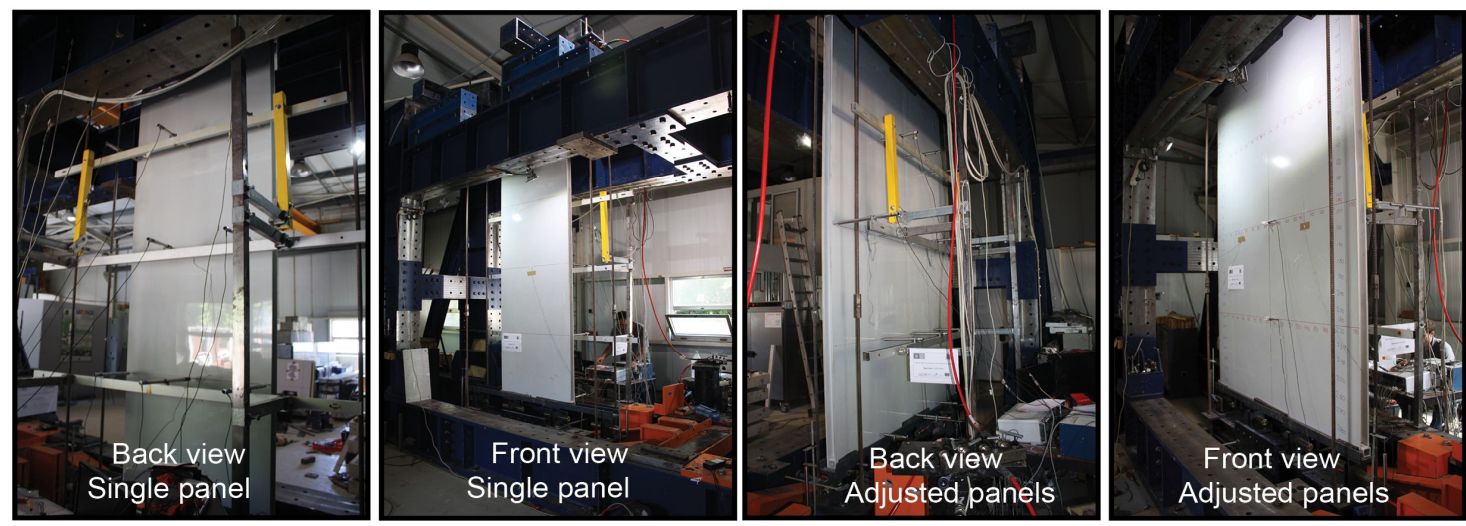

778

779

780

Fig. 16. Test setup for single panel and two jointed panels.

781

782

783

784

785

786

787

788

789

790

791

792

793

794

795

796

797

798

799

800

801

802

803

804

805

806

807 
Abdolpour, H.; Escusa, G.; Sena-Cruz, J.; Valente, I.; Barros, J. (2017) “Axial performance of jointed sandwich wall panels.” Journal of Composites for Construction, 21(4): 04017009 1 04017009-12.

808

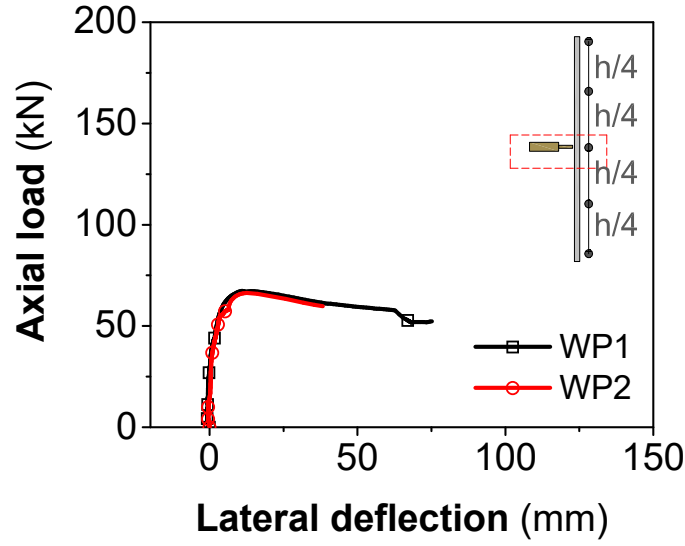

(a)

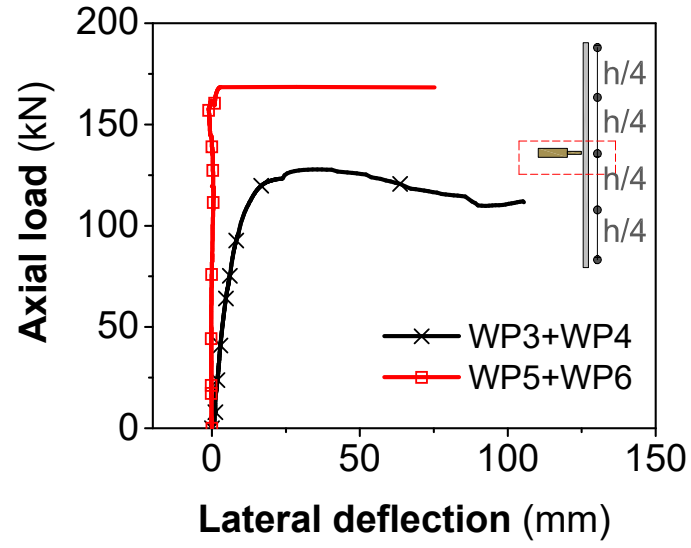

(b)

Fig. 17. Axial load vs. mid height lateral deflection: (a) single panel; (b) two jointed panels. 
Abdolpour, H.; Escusa, G.; Sena-Cruz, J.; Valente, I.; Barros, J. (2017) “Axial performance of jointed sandwich wall panels.” Journal of Composites for Construction, 21(4): 04017009 1 04017009-12.

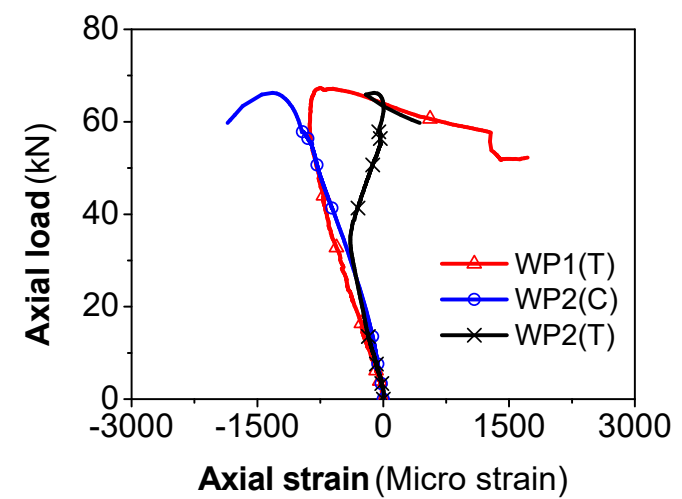

(a)

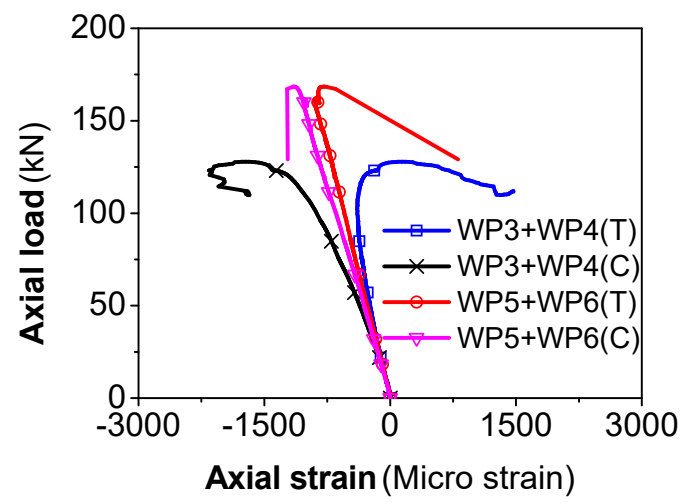

(b)

Fig. 18. Load vs. axial strain: (a) single panel compressive strain; (b) two adjusted panels. 
Abdolpour, H.; Escusa, G.; Sena-Cruz, J.; Valente, I.; Barros, J. (2017) “Axial performance of jointed sandwich wall panels.” Journal of Composites for Construction, 21(4): 04017009 1 04017009-12.
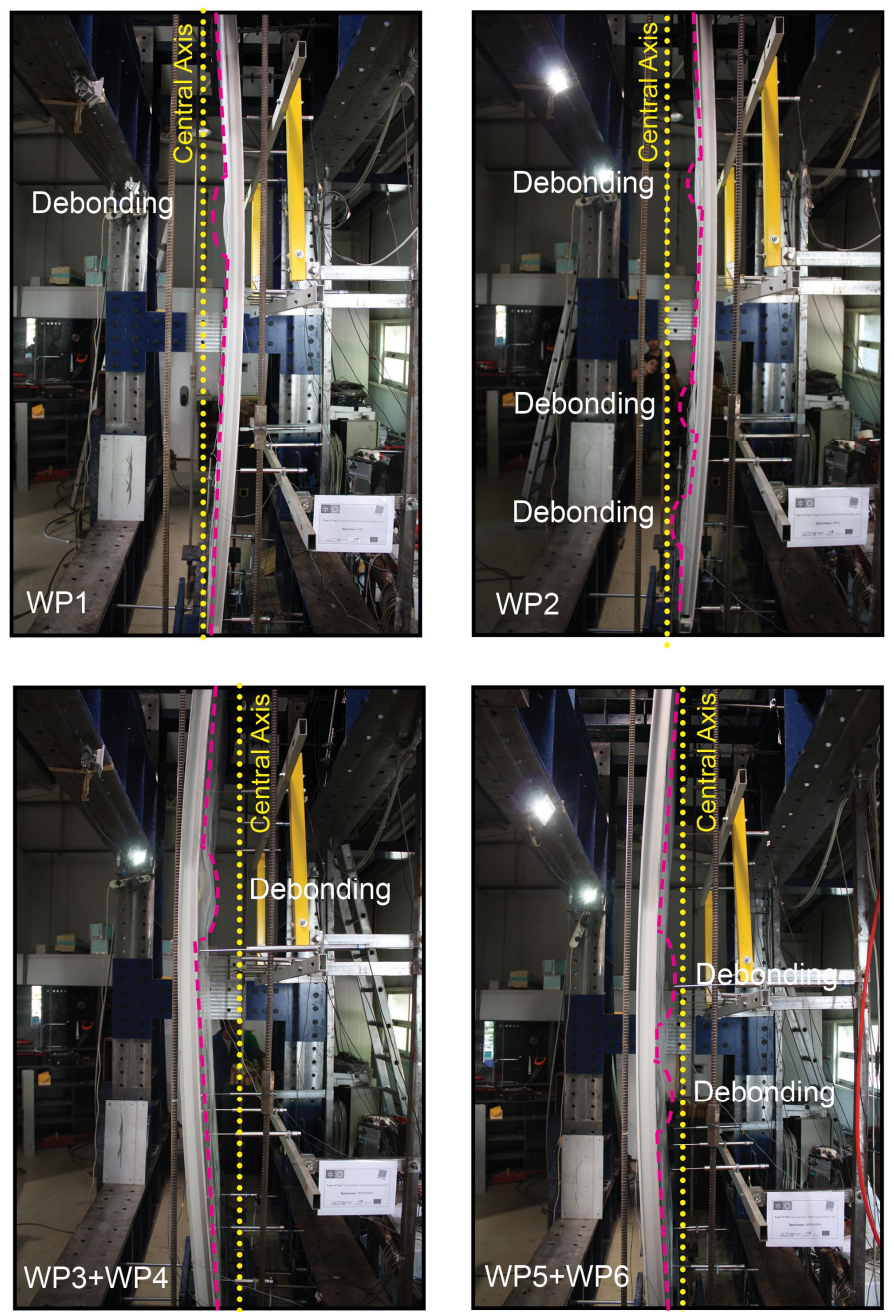

816

Fig. 19. Failure modes observed in axially loaded single panel and two jointed panels. 
Abdolpour, H.; Escusa, G.; Sena-Cruz, J.; Valente, I.; Barros, J. (2017) “Axial performance of jointed sandwich wall panels.” Journal of Composites for Construction, 21(4): 04017009 1 04017009-12.

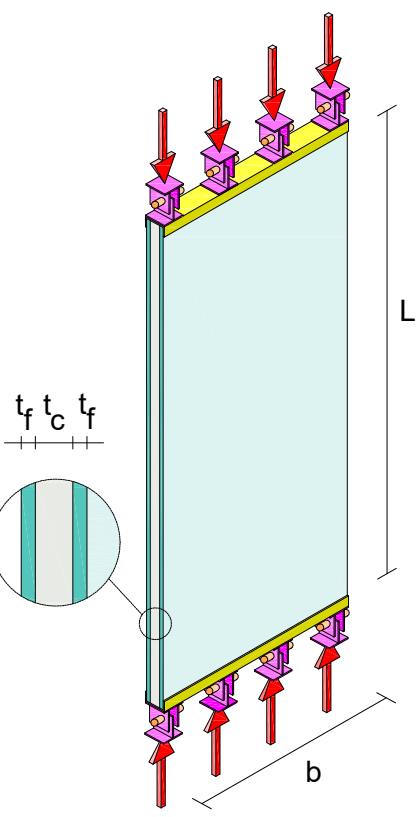

(a)
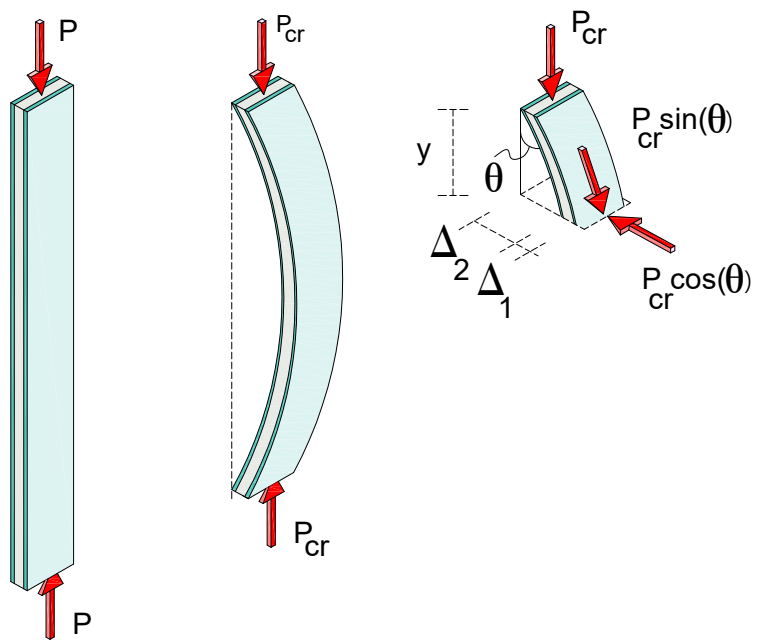

(c)

(d)

Fig. 20. Axially loaded wall panel: (a) schematic of axially loaded panels; (b) strut subjected to axial load; (c) deformed shape of strut and (d) free body diagram of the bucked strut. 
Abdolpour, H.; Escusa, G.; Sena-Cruz, J.; Valente, I.; Barros, J. (2017) “Axial performance of jointed sandwich wall panels.” Journal of Composites for Construction, 21(4): 04017009 1 04017009-12.

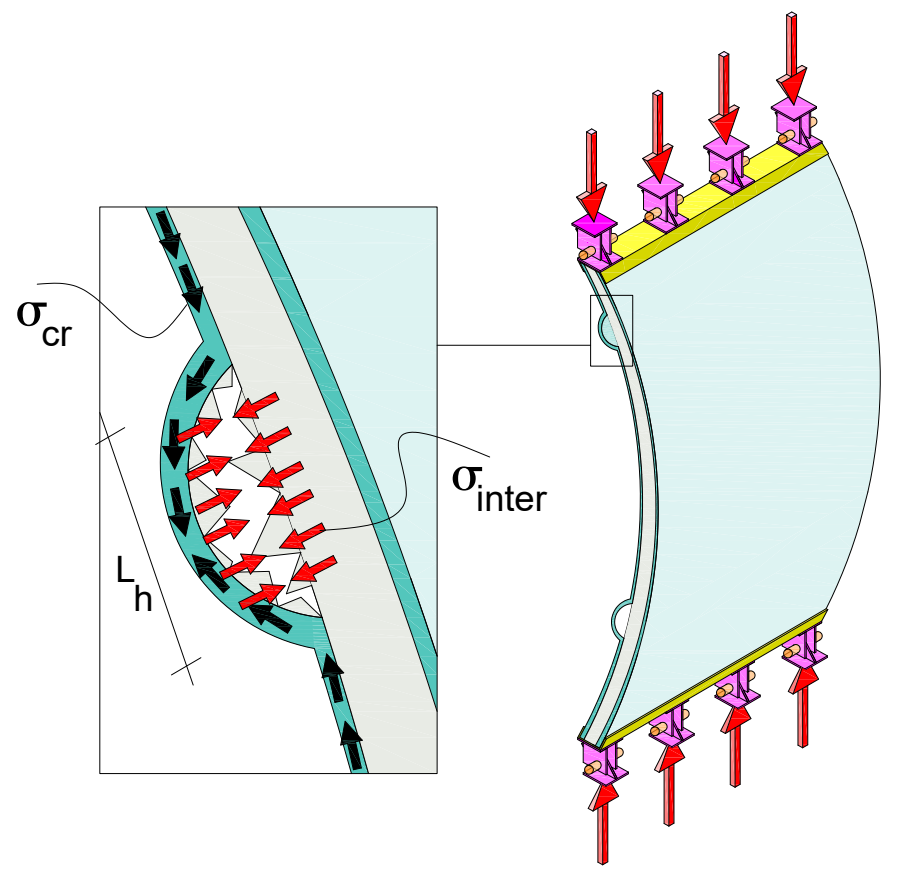

Fig. 21. GFRP skin wrinkling model and stresses. 
Abdolpour, H.; Escusa, G.; Sena-Cruz, J.; Valente, I.; Barros, J. (2017) "Axial performance of jointed sandwich wall panels." Journal of Composites for Construction, 21(4): 04017009 1 04017009-12.

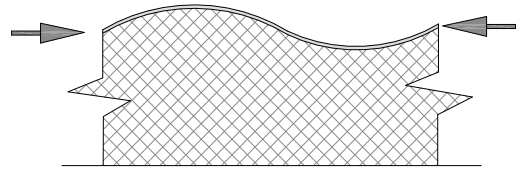

(I)

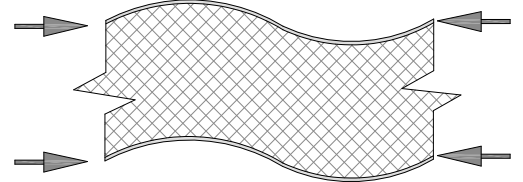

(II)

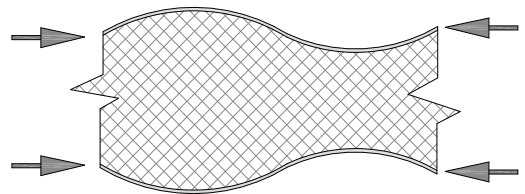

(III)

Fig. 22. Principal types of wrinkling instability: (I) rigid base; (II) antisymmetric wrinkling and (III) symmetric wrinkling (Allen 1969). 